\title{
Entre a história e a literatura, os Becos da memória dos afro-descendentes
}

\author{
VALeria Rosito \\ Instituto Superior de Educação do Rio de Janeiro
}

o século IV a.C., Aristóteles já pensava em sua Poética as fronteiras entre Literatura e História, postulando que "a Poesia encerra mais filosofia e elevação do que a História". Explica que a diferença é que esta narra acontecimentos particulares, e aquela, fatos que podiam acontecer. Na contracorrente do século XIX, Nietzsche problematiza a "história monumental", sugerindo, muito antes da invenção do cinema, que sua narrativa resulta de um processo de edição, marcado pela alternância entre o lembrar e o esquecer. Contra o pensamento dominante de sua época, o filósofo alemão reitera que a memória feita somente de lembranças equivale ao enterro dos vivos pelos mortos, ou, em outros termos, que o passado seja "coveiro do presente". A imagem inusitada encerra a recusa aos mecanismos de continuidade histórica e a revisitação do próprio conceito de genealogia. Entende-se, portanto, por que o esquecer torna-se tão importante quanto o lembrar quando se trata de apostar no futuro, reescrevendo a história com novas perspectivas, libertando-nos de uma memória sempre que a produção do novo assim o exigir. Entende-se, também, o estreitamento dos laços entre literatura e história, uma vez que o exercício da imaginação inverte cronologias, "descobre" novos sentidos para discursos hegemônicos, legitima lugares de enunciação não reconhecidos e, acima de tudo, aniquila hierarquias entre verdade e verossimilhança.

É no espírito dessa aliança que Becos da memória, de Conceição Evaristo, se constitui como biografia romanceada da autora de Ponciá Vicêncio. A erradicação de uma favela e as múltiplas memórias e temores que se fazem ouvir por todos os seus becos se misturam numa ficção singular, por meio da qual o universal se realiza nas entranhas das narrativas mais particularizadas. $\mathrm{Na}$ contramão da estética hiper-real, Becos da memória faz desfilar alegorias encar- 
nadas em personagens como Bondade ou Vó Rita. Um agregado de cujo passado pouco se sabe e uma velha parteira que "dorme embolada com a Outra" atendem a uma dimensão limítrofe do humano, acolhendo os mais miseráveis dentro da miséria: seja a menina abusada pelo pai, seja a leprosa inominável, ambas sem qualquer outra interlocução no espaço simbólico da favela. Contradições e heterogeneidade na retratação apurada dos personagens impedem o maniqueísmo fácil e o efeito perverso da eventual estereotipação que alimenta o discurso da vítima. Ao contrário, deparamo-nos com a coexistência de misérias e grandezas, normalmente sem entrada nos noticiários ou na escrita hegemônica: "Ele [Bondade] sabia que há pobres que são capazes de dividir, de dar o pouco que têm e que há pobres mais egoístas em suas misérias do que os ricos nas farturas deles" (p. 38). Além de Fuinha, marido e pai estuprador, faz parte desse rol D. Santinha, que espanca a nora de oito meses de gravidez para matar-lhe a criança e incriminar o próprio filho.

Ainda no tocante à caracterização, o esmero emprestado às feições dos menores personagens - aqueles que são observados de relance, como CidaCidoca, a prostituta "do rabo de ouro", Dora, Filó Gazogênia, entre muitos outros - não se faz menor do que o cuidado com os traços daqueles que impulsionam a narrativa, como Tio Totó, Maria-Velha, Joana, Maria-Nova, todos integrantes de uma mesma família de narradores. A solidão e o desespero do patriarca, que sobreviveu à morte de companheiras e filhos no deslocamento do campo para a cidade, sua última mulher, Maria-Velha, que "ria para dentro", e Mãe Joana, que "nem para dentro ria" (p. 131), são especificidades entrelaçadas com marcas estruturais da luta de classes que, nos termos de Conceição Evaristo, se confundem, no Brasil, com as marcas da discriminação racial, sempre dissolvida no mito da democracia racial. A proximidade espacial dos barracos e das mansões ("O bairro nobre e a favela eram vizinhos”) acentua a intimidade promíscua entre aquelas que, como Maria-Velha e Joana, "encontraram no fogão, no tanque e nas casas das patroas modos de sobrevivência" (p. 131).

A linguagem literária flagra, metonimicamente, as disparidades da contigüidade perversa banalizada no cotidiano das classes abastadas. A empregada doméstica que arruma as jóias da patroa depois da festa emblematiza, adicionalmente, a alienação simbólica da mulher negra num espelho que a faz desejar-se outra: "Como D. Laura era bonita! Muito alta, loira, com os olhos 
da cor daquela pedra das jóias. Ditinha gostava muito de D. Laura e D. Laura gostava muito do trabalho de Ditinha. Olhando e admirando a beleza de D. Laura, Ditinha se sentiu mais feia ainda. Baixou os olhos envergonhada de si mesma" (p. 94, grifos acrescentados). Vetada duplamente à totalidade do ser - não pode ser D. Laura e não deve ser ela mesma -, Ditinha, então, "colocou o broche no peito, só que do lado de dentro do peito, junto dos seios, sob o sutiã encardido" (p. 99).

Os limites entre o dentro e o fora saltam na materialidade dos corpos negros, valorizados como elementos-chave na organização simbólica do espaço, do tempo e do cosmos. Os efeitos do trabalho alienado das lavadeiras são ressaltados no conjunto de contrastes, lavrado formalmente por frases sem conjunções: "Com a persistência da chuva, era pior. Tudo ia ficando úmido, tudo mofo, tudo barro, tudo lama e frio. Os agasalhos eram poucos. As roupas das patroas não secavam. O trabalho custava tanto e pouco rendia. $\mathrm{O}$ sol, às vezes, aparecia trazendo um tempo esperançoso no céu. As roupas corriam para os varais e, mal eram penduradas, retornavam molhadas e, às vezes, sujas às bacias no canto do barraco. "Era preciso lavá-las de novo" (p. 128, grifos acrescentados). A ação indiferente da natureza torna-se irônica no choque entre carência e desperdício, coexistentes porque socialmente produzidos.

Nesse sentido, a escrita como mediação privilegiada entre o mundo e o homem ganha também ressignificação a partir desse lugar de enunciação específico, que a ancora aos corpos de seus escritores negros, eles próprios, como sua escrita, inscritos sobre a terra em que pisam: "Mãe Joana sabia fazer simpatia para o sol aparecer. Quando dava alguma aragem, ela ia lá para trás de casa e desenhava no chão um grande sol cheio de pernas compridas" (p. 128). Maria-Nova é herdeira desse conceito de escrita visceral. Para romper com a história monumental hegemônica, a menina precisa saber sobre sua gente, sobre seus amores, perigos e mistérios. Por isso, denuncia também o caráter conservador da escola, aprendendo no fundo das dores - sua e de sua gente - novos sentidos para velhos tópicos acadêmicos, como a "Libertação dos Escravos": "Maria- Nova levantou-se dizendo que, sobre escravos e libertação, ela teria para contar muitas vidas. Que tomaria a aula toda e não sabia se era bem isso que a professora queria. Tinha para contar sobre uma senzala que, hoje, seus moradores não estavam libertos, pois não tinham nenhuma condição de vida. [...] Eram muitas as histórias, nascidas de uma outra Histó- 
ria, apesar de muitas vezes distantes no tempo e no espaço. Pensou em Tio Totó. Isto era o que a professora chamava de homem livre?” (p. 137-138).

No espaço da inclusão perversa, Maria-Nova e Negro Alírio, militante sindicalista perseguido por suas ações reivindicatórias dos direitos dos trabalhadores, se afiguram como messias de uma nova ordem, realizando a emancipação dos oprimidos por novas formas de ler e de escrever. Note-se que não se trata da valorização da cultura letrada, strictu senso, mas de sua apropriação crítica e, até mesmo, de sua subversão. Vida e leitura tornam-se uma mesma experiência, uma vez que suportes e modos convencionais, como vimos, cedem lugar aos gestos e à materialidade dos corpos que se instrumentalizam para escrever diferente. Tio Totó fora o primeiro a perceber a sabedoria em se ler "o dizer por detrás do escrito". Como Tio Totó, Negro Alírio "sabia ler o que estava e o que não estava escrito" (p. 61). Referências em maiúsculas a esse personagem realçam o caráter messiânico de sua existência: "O Homem leu nos olhos, nas feições e no porte do Coronel os modos de mando" (p. 65). Como Negro Alírio, o forasteiro recém-chegado em que se espelha, Maria-Nova apreende sua missão no espaço comunitário: "Olhou novamente para Negro Alírio. Quis falar com ele sobre o que já havia decidido. Calou, sabendo, entretanto, que iria adiante com ele. Sim, ela iria adiante. Um dia, ela haveria de narrar, de fazer soltar as vozes, os murmúrios, os silêncios, o grito abafado que existia, que era de cada um e de todos. Maria-Nova, um dia, escreveria a fala de seu povo" (p. 161).

Ao redimensionar o tempo histórico, Walter Benjamin retoma as reflexões de Nietzsche, seu antecessor e conterrâneo, sugerindo que "a história é objeto de uma construção cujo lugar não é o tempo homogêneo e vaquio, mas um tempo saturado de agoras". Os relâmpagos fotográficos, que congelam a fluidez dos mitos dominantes, seja na história, seja na literatura, rompem com o aparente continuum entre passado e presente, desfraldando, na descontinuidade, novas forças emancipatórias para um futuro verdadeiramente novo. O filósofo alemão referencia o quadro Angelus Novus, do pintor Paul Klee, para sintetizar tal visão: "Representa um anjo que parece querer afastar-se de algo que ele encara fixamente. Seus olhos estão escancarados, sua boca dilatada, suas asas abertas. O anjo da história deve ter esse aspecto. Seu rosto está dirigido para o passado. Onde nós vemos uma cadeia de acontecimentos, ele vê uma catástrofe única, que acumula incansavelmente ruína sobre ruína e as dispersa a 
nossos pés. Ele gostaria de deter-se para acordar os mortos e juntar os fragmentos. Mas uma tempestade sopra do paraíso e prende-se em suas asas com tanta força que ele não pode mais fechá-las. Essa tempestade o impele irresistivelmente para o futuro, ao qual ele vira as costas, enquanto o amontoado de ruínas cresce até o céu. Essa tempestade é o que chamamos progresso" (BENJAMIN, 1994: 226).

Até onde podemos perceber, Becos da memória, de Conceição Evaristo, ostenta, com a maestria de seu discurso literário, possibilidades de releitura do passado e de recomposição de ruínas históricas dispersadas pela História e pela Literatura dominantes. Com os personagens desenraizados e os próprios becos dragados pelos tratores e máquinas do progresso, enveredamos pelas narrativas particulares e afastadas do monumentalismo - histórico ou literário - para nos defrontarmos com nosso próprio inacabamento simbólico enquanto nação, temerosos de enfrentar, ao contrário de Maria-Nova, em seu último sono-sonho, o coração enorme de Vó Rita, em que cada batida e cada pulsar faz nascer "todos os homens: negros, brancos, azuis, amarelos, cor-derosa, descoloridos". Uma visão utópica? Certamente, mas não ingênua; afinal, como Tio Totó ensina, "Os sonhos dão para o almoço, para o jantar, nunca", e se somos alimentados pelos sonhos até certa hora da vida, mais adiante "a gente precisa ver o sonho acontecer" (p. 50).

\section{Referências Bibliográficas}

BENJAMIN, Walter. Magia e técnica, arte e política: ensaios sobre literatura e história da cultura. São Paulo: Brasiliense, 1994.

EVARISTO, Conceição. Becos da memória. Belo Horizonte: Mazza, 2006. 